\title{
Endoscopic Endonasal Transsphenoidal Pituitary Surgery: Experience of 80 Cases
}

\author{
Endoskopik Endonazal Transsfenoidal Hipofiz Cerrahisi: \\ 80 Olguluk Deneyim
}

\author{
Murat KORKMAZ ${ }^{1}$, Ali Erdem YILDIRIM ${ }^{2}$, Arif OSUN ${ }^{1}$, Fatih ALAGOZ ${ }^{2}$, Denizhan DIVANLIOGLU², \\ Ergun DAGLIOGLU², Ahmet Deniz BELEN ${ }^{2}$
}

${ }^{1}$ Evliya Celebi Education and Research Hospital, Department of Neurosurgery, Kütahya, Turkey

${ }^{2}$ Ankara Numune Education and Research Hospital, Department of Neurosurgery, Ankara, Turkey

Corresponding Author: Murat KORKMAZ / E-mail: drmuratkorkmaz35@gmail.com

\begin{abstract}
AIM: Surgical approaches to the pituitary have undergone numerous refinements over the last 100 years. The fully endoscopic transsphenoidal approach has gained widespread use all around the world. We report the results of a consecutive series of patients who underwent pituitary surgery using a pure endoscopic endonasal approach and the results of the evaluation of the efficacy and safety of this procedure.

MATERIAL and METHODS: We retrospectively reviewed the hospital database of 80 consecutive pituitary adenomas that were resected with the purely endoscopic endonasal transsphenoidal technique.

RESULTS: The preoperative clinical condition of the patients, hormone profile, visual field, computed tomography and magnetic resonance imaging findings, and the Hardy-Vezina and Knosp scores were evaluated and revealed the importance of the parameters for surgery. Surgical technique, postoperative clinical condition of the patients, hormone profile, complications and follow-up period were reviewed.

CONCLUSION: Endonasal endoscopic pituitary surgery is a safe and effective surgical technique.

KEYWORDS: Endonasal surgery, Endoscopic surgery, Pituitary gland, Transsphenoidal hypophysectomy
\end{abstract}

Öz

AMAÇ: Hipofiz bezine uygulanan cerrahi tekniklerde son yüzyıl içinde çeşitli yenilikler geliştirilmiştir. Tamamen endoskopik transsfenoidal girişim tüm dünyada yaygın kullanım alanı bulmuştur. Çalışmanın amacı, ardışık hastalarda sadece endoskopik olarak uygulanan hipofiz cerrahisinin etkinliğini ve güvenilirliğini araştırmaktır.

YÖNTEM ve GEREÇLER: Retrospektif olarak sadece endoskopik endonazal transsfenoidal cerrahi uygulanan 80 ardışık hipofiz adenomlu hasta, hastane veri tabanı kullanılarak incelendi.

BULGULAR: Hastaların preoperatif klinik durumu, hormon profili, görme alanı, bilgisayarlı tomografi ve manyetik rezonans görüntüleme bulguları, Hardy-Vezina ve Knosp skorları değerlendirilerek cerrahideki önemleri tartışıldı. Uygulanan cerrahi teknik, hastaların postoperatif klinik durumu, hormon profili, komplikasyonlar ve takip süreci değerlendirildi.

SONUÇ: Endoskopik hipofiz cerrahisinin güvenli ve etkin bir tedavi yöntemi olduğu kanaatine varıldı.

ANAHTAR SÖZCÜKLER: Endonazal cerrahi, Endoskopik cerrahi, Hipofiz cerrahisi, Transsfenoidal hipofizektomi

\section{INTRODUCTION}

Prior to the mid-1800s the pituitary's function and pathology were unknown. The transcranial approach to the pituitary was first used in 1889 by Sir Victor Horsely, who performed transfrontal surgery to resect a pituitary adenoma $(5,8)$. He went on to publish a total of ten operations in 1906, reporting a mortality rate of $20 \%$. Several neurosurgeons then followed suit, and Paul and Caton performed the transtemporal approach with little success. The transcranial approach came with a high mortality rate of $20-80 \%$, and so it was ultimately abandoned for a less invasive approach.
Transsphenoidal surgery was first proposed by Giordano, who was chief of surgery at the University of Venice. He based his proposal on anatomic studies. Herman Schloffer from Innsbruck Austria became the first to document transsphenoidal pituitary surgery in 1907. He did this via a 3-stage surgery where he performed a transfacial incision, a lateral rhinotomy along the left side of the nose up to the glabella, and reflecting the nose to the right. The next stage involved removal of the middle and inferior turbinates as well as the septum. He removed the anterior and posterior ethmoids. In the final stage, he removed the volmer and rostrum of the sphenoid to finally arrive at the sella. Discontented with Schloffer's approach, Cushing in 1910 incorporated Halstead's 
sublabial incision and Kocher's submucosal resection of the septum to perform a sublabial transeptal transsphenoidal approach, which is the surgery that is used to this day (8).

The versatility of the transsphenoidal approach was greatly expanded by using fluoroscopy and the operating microscope but more modifications were needed for greater visualization and accuracy. In the 1990s, a collaboration of neurosurgeons and otolaryngologists described the pure endoscopic transsphenoidal technique in which the endoscope is used alone for visualization without an accompanying microscope or transsphenoidal retractor (8).

Although there are complications such as anterior pituitary insufficiency, diabetes insipidus, cerebrospinal fluid (CSF) fistulas, carotid artery injuries, hypothalamic injuries, loss of vision, and meningitis (6), the development of neuroendoscopy and the popularization of transsphenoidal endoscopic-guided pituitary surgery have been associated with better tumor resection results. Detailed preoperative evaluation of the patient and the experience of the surgeon are two of the major factors to decrease the mortality and the morbidity rate (7).

\section{MATERIAL and METHODS}

A total of 80 patients with pituitary tumor who underwent purely endoscopic endonasal transsphenoidal pituitary surgery during the period of August 2005 to September 2011 in the Department of Neurosurgery, Ankara Numune Education and Research Hospital were included in this retrospective study.

All patients were preoperatively assessed clinically and radiologically [plain $\mathrm{x}$-ray skull, paranasal sinus and sellar computed tomography (CT) (Toshiba Activion 16 multislice CT; Tokyo, Japan) and contrast enhanced hypophysis magnetic resonance imaging (MRI) (GE 1.5 T Sigma Excite; New York, USA)]. Preoperative visual field analysis (Humphrey Instruments, Carl Zeiss) and anterior pituitary hormone analysis (ACTH, early morning cortisol level, urine cortisol, PRL, TSH, T3, T4, GH, IGF-1, FSH, LH, E2, and free testosterone) were evaluated. The dimension of the adenoma, suprasellar and cavernous sinus extension, condition of the sellar floor, septation and pneumatization of the sphenoid sinus and paranasal pathological conditions were recorded. All of the patients were classified according to the Knosp, Hardy and Vezina classifications.

All of the patients were operated with the purely endoscopic endonasal technique. One hour before the operation, intravenous $1 \mathrm{gr}$ ceftriaxone was used for prophylaxis. Binostril endoscopic endonasal surgery was performed with $0^{\circ}$ and $30^{\circ}$ rigid wide angle endoscopes (Karl Storz, $\mathrm{GmbH} \&$ Co., Tuttlingen, Germany). Mean operation duration was 180 minutes.

In the early postoperative period, the patients were taken to the intensive care unit (ICU). Neurological examination and confrontation visual field assessment results and the fluid balance were recorded. Minirin (deamino 8-D-arginine vasopressin DDAVP) nasal spray was used in cases with $300 \mathrm{ml} /$ hr urinary output and urinary density 1005 or lower. Histologic examination was performed at the pathology department of the same hospital. Follow-up MRI was performed at the first postoperative day and after the third month. The patients were discharged on the fourth postoperative day.

\section{RESULTS}

Forty-three of the patients (53.8\%) were female and the average age was 47 years (20-80 years). Twenty of the cases (25\%) were recurrent pituitary adenomas and $45 \%$ of them (9 cases) were histologically non-functional. We found that 28 cases (35\%) had hypopituitarism and most of them were nonfunctional adenomas (Table I).

Automated perimetry showed that 41 patients (51.25\%) had visual field defects. Unilateral temporal hemianopsia was the most common (48.7\%) type of visual field defect (Table II).

Radiologic evaluation showed that $81.25 \%$ (65/80) cases were of the sellar type and the rest had presellar type pneumatization. Most of the adenomas were macroadenoma $(81.25 \%)$ and there was no giant adenoma. Serum hormone levels revealed that $61.5 \%$ of the macroadenomas were non-functional, whereas $86.6 \%$ of the microadenomas were functional.

Histologic evaluation showed that most of the adenomas were typical adenomas (85\%). Non-functional types were $52.5 \%$ and somatotropic types were $18.75 \%$ of the adenomas. Half of the atypical adenomas were non-functional (Table III) .

Adenomas were evaluated by MRI according to the Knosp, Hardy and Vezina classifications (Table IV). Ten percent of the adenomas were Knosp Grade 0 and $37.5 \%$ were Grade I. Among the non-functional adenomas, there was no Knosp 0 tumor. According to the Hardy classification, $53.3 \%$ of the adenomas were Stage $A$ and the asymmetrical superior extension rate was higher $(21.9 \%)$ in non-functional adenomas then functional cases (8.8\%). Evaluation of the adenomas with the Vezina classification revealed that most of the adenomas were Grade II (43.8\%) and the sellar destruction rate was higher in non-functional adenomas (21\%).

Table I: Adenoma Types of the Patients with Hypopituitarism

\begin{tabular}{|l|r|r|}
\multirow{2}{*}{ Adenoma Type } & \multicolumn{2}{|c|}{ Hypopituitarism } \\
\cline { 2 - 3 } & $(+)$ & $(-)$ \\
\hline Non-functional & 26 & 16 \\
\hline Prolactinoma & 1 & 7 \\
\hline Somatotropinoma & 1 & 14 \\
\hline Corticotropinoma & 0 & 12 \\
\hline PRL+GH & 0 & 2 \\
\hline PRL+ACTH & 0 & 1 \\
\hline Total & 28 & 52 \\
\hline
\end{tabular}

PRL: prolactinoma, GH: somatotropinoma, $\mathbf{A C T H}$ : corticotropinoma. 
There was no surgical complication except CSF leakage (3.8\%) which was treated by surgical repair. In 9 patients $(11.3 \%)$, postoperative diabetes insipidus was observed and managed by medical treatment.

\section{DISCUSSION}

Pituitary adenomas are divided into two categories. They can be secretory (hormonally active) or non-secretory (hormonally inactive). The hormonally inactive pituitary adenomas require surgery when they cause mass effect causing a hypopituitary event, vision changes, pituitary apoplexy (hemorrhage into the adenoma itself), or severe headaches (7).

Hormonally active pituitary adenomas include prolactinomas that are first treated medically with a dopamine agonist such as bromocriptine. In acromegaly and Cushing's disease (21), surgery can be offered as a primary therapy; however, there are several different medical therapies that can be used to treat these conditions, such as somatostatin analogs and octreotide for acromegaly (12).

Pre-operative planning involves a multi-disciplinary approach including several different specialties: an otolaryngologist, an ophthalmologist, a neurosurgeon, an endocrinologist and potentially a radiation oncologist $(5,17)$.

The otolaryngologic evaluation includes a complete history, and a thorough head and neck examination particularly focusing on flexible endoscopic evaluation of the sinonasal anatomy. It is important to note whether or not the patient will need a septoplasty prior to surgery. Ophthalmological evaluation is very important, not only for visual acuity,

Table II: Visual Field Defects of the Cases

\begin{tabular}{|c|c|c|c|c|c|c|c|}
\hline & $\begin{array}{l}\overline{0} \\
\frac{0}{0} \\
\frac{7}{8} \\
\frac{2}{2} \\
\frac{1}{2} \\
z\end{array}$ & 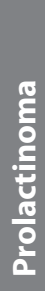 & 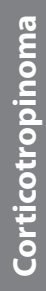 & 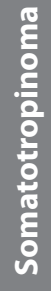 & 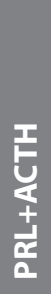 & $\frac{\text { 工 }}{\frac{+}{\alpha}}$ & 롱 \\
\hline Left THA & 8 & 1 & 1 & - & - & - & 10 \\
\hline Right THA & 5 & 1 & 1 & 3 & - & - & 10 \\
\hline $\mathrm{Bi}-\mathrm{THA}$ & 6 & 2 & 1 & 3 & - & - & 12 \\
\hline Left amaurosis & 5 & - & - & - & - & - & 5 \\
\hline Right amaurosis & - & - & 1 & - & - & - & 1 \\
\hline Left amaurosis+Right THA & 1 & - & - & - & - & - & 1 \\
\hline Right amaurosis+ Left THA & 1 & 1 & - & - & - & - & 2 \\
\hline Total & 26 & 5 & 4 & 6 & 0 & 0 & 41 \\
\hline
\end{tabular}

THA: Temporal hemianopsia.

Table III: Types of the Adenomas

\begin{tabular}{|l|c|c|c|c|c|c|} 
& Non-functional & GH & PRL & ACTH & PRL+GH & PRL+ACTH \\
\hline Typical & 36 & 13 & 5 & 11 & 2 & 1 \\
\hline Atypical & 6 & 2 & 3 & 1 & - & - \\
\hline Total & 42 & 15 & 8 & 12 & 2 & 1
\end{tabular}

Table IV: Evaluation of the Adenomas according to Knosp, Hardy and Vezina Classifications

\begin{tabular}{|c|c|c|c|c|c|}
\hline Knosp & $\%$ & Hardy & $\%$ & Vezina & $\%$ \\
\hline Grade 0 & 10 & Stage A & 53.3 & 0 & 6.3 \\
\hline Grade 1 & 37.5 & Stage B & 17.4 & I & 18.7 \\
\hline Grade 2 & 18.75 & Stage C & 13.3 & II & 43.8 \\
\hline Grade 3 & 18.75 & Stage D & 16 & III & 18.7 \\
\hline Grade 4 & 15 & Stage $\mathrm{E}$ & 0 & IV & 12.5 \\
\hline Total & 100 & & 100 & & 100 \\
\hline
\end{tabular}


but more importantly for documentation of visual fields. It is important to document the fields so that they may be compared with post-operative visual field testing to see if there is any improvement or deterioration of the patient's visual fields.

It is also important to review the pre-operative imaging and note the locations of the carotid canal and optic canal and evaluate pneumatization of the sphenoid $(3,16)$. Most of the studies mention that preoperative planning of the surgery should be performed with the Hardy and Vezina classification. We believe that the Knosp classification is also as important as the Hardy-Vezina classification. The lateral extension of the adenoma should be visualized. The relationship of the adenoma with the internal carotid artery is a major definitive factor for the success of the surgery.

The sphenoid sinus develops from pneumatization of the sphenoid bone, which occurs rapidly between the ages of 5 and 7 years. The process is completed usually by age of 20 . The roof of the sphenoid sinus is formed by the planum sphenoidale anteriorly and the sella posteriorly. The lateral walls of the sphenoid sinus contain several very important structures. These include the Vidian canal that runs laterally along the floor as well as the carotid arteries within the carotid canal latero-inferior, and the optic canal laterosuperior. One of the important landmarks that must be found endoscopically is the sphenoid ostium $(1,3,16)$. This is located medial to the superior turbinate and lateral to the septum. After sphenoidotomy and posterior septectomy as well as resection of the sphenoid septum, there are several structures that will come into view. First is the sella, which is a protuberance seen in the midline. The planum sphenoidale is located anteriorly and the clivus posteriorly. At 5 and 7 o'clock the carotid artery, carotid canal and the optic nerve and optic canal can be visualized. In between the two there is a triangular shaped fossa, called the carotico-optic recess. It is important to identify this structure because the ophthalmic artery that arises medially off the carotid is associated with this space (16).

Post-operatively, it is important to observe these patients in the ICU for at least the first night with routine neurological checks and monitoring of urine output. It is important to monitor for diabetes insipidus, which can occur immediately post-operatively in up to 20 to $60 \%$ of the patients. Antibiotics are routinely administered; however, there is just no good data out there to support a specific antibiotic, and it often depends on the surgeon. Steroids are routinely given with a stress dose prior to surgery and continued steroid administration post-operatively. Hormone replacement is administered as necessary by the endocrinologist.

Senior et al. (19) performed 193 surgeries from March 2000 to 2007. The tumor sizes were divided between 0 to $10 \mathrm{~mm}, 11$ to $20 \mathrm{~mm}$, and greater than $21 \mathrm{~mm}$, which were the majority of the tumors. Secreting adenomas accounted for $30 \%$ of the surgeries, and the non-secreting adenomas for $54 \%$. The mean post-operative stay for this study was 3.6 days. Complications were again acceptable, with a $1 \%$ rate of meningitis, and 1 mortality in the group. However, the post-operative CSF leak rate was higher than that reported in the literature, reaching as high as $10 \%$.

Cappabianca et al. reported 146 consecutively treated patients who underwent an endoscopic endonasal transsphenoidal approach to the sellar region for resection of pituitary adenomas and the surgical complication rate was $8.9 \%$ (4). In the literature, the overall surgical complication rate is $8.9 \%$ $32.5 \%(10,18,20)$. In this study, the surgical complication rate was $3.75 \%$. White et al. (22) compared 50 patients undergoing sublabial transseptal transsphenoidal surgery from 1996 to 1999, as well as 50 patients undergoing endoscopic surgery from 2000 and 2002. There was no difference in the intraoperative blood loss and the incidence of diabetes insipidus between the two groups. However, they showed that endonasal complications were much lower in the endoscopic group compared to the sublabial group.

Chiasmatic decompression is the primary objective of transsphenoidal hypophysectomy for a macroadenoma compressing the optic chiasm. Approximately 5-14\% of macroadenomas are inadequately identified during surgery because of firm, non-pliable, fibrous lesions that are not easy to remove by suction and curettage. For a residual secreting tumor, adjunct treatment may include residual chiasm compression and cavernous sinus invasion, and gamma knife radiosurgery but transcranial surgery may be needed for adequate chiasmatic decompression and tumor debulking. MRI findings before transsphenoidal hypophysectomy related to the structural integrity of the tumor are useful for ensuring successful chiasmatic decompression of a macroadenoma (2).

The mortality rate due to pituitary tumors is low. Suprasellar expansion of the macroadenoma into the optic chiasm and the cranial nerves adjacent to the cavernous sinus are the main reasons for the morbidity rate and permanent visual loss, ophthalmoplegia, and other neurological complications that may occur. Lateral extension may cause partial or complete engulfment of the carotids. For pituitary microadenomas, the cure rate is greater than $50 \%$ on complete excision. The tendency for residual tumor to remain is higher for tumours larger than $1 \mathrm{~cm}$ and may require additional treatment such as radiotherapy or radiosurgery. Earlier studies report that the incidence of postoperative CSF leak is between 1.5 and $4.2 \%$ (9). Macroadenoma surgery has a greater CSF leak risk than microadenoma surgery. Multilayered closure, direct suturing of grafts to dural edges, use of biological glues, and coverage with vascularized septal mucosal flap decrease the incidence of postoperative CSF leaks $(11,15)$. We used a pedicled nasal septal flap for the reconstruction of the sellar base and we observed that our CSF leakage rate was lower than the rates in the literature.

Basically the advantages of truly endoscopic pituitary surgery are numerous. There is reduced operative time, superior illumination and magnification, diminished intra-operative blood loss, and enhanced differentiation between normal 
glandular tissue and tumor $(7,13,17)$. There are less endonasal complications (14), reduced hospital stays, better patient satisfaction, no postoperative nasal packing, and no risk of tooth numbness. There is also less risk for septal perforation without the submucosal bilateral dissection of the septum that is used in the traditional approach (14).

\section{CONCLUSION}

Purely endoscopic surgery for sellar lesions is safe and effective, and it is obvious that the endoscope provides important intraoperative visualization that is not possible to obtain with the tunnel vision of the microscope. Large lesions may be resected adequately by the technique, without a high rate of complications. Preoperative detailed evaluation of the patient, team work and the experience of the surgeon are major factors affecting the result of the surgery.

\section{REFERENCES}

1. Abuzayed B, Tanriover N, Ozlen F, Gazioglu G, Ulu MO, Kafadar AM, Eraslan B, Akar Z: Endoscopic endonasal transsphenoidal approach to the sellar region: Results of endoscopic dissection on 30 cadavers. Turk Neurosurg 19(3): 237-244, 2009

2. Boxerman JL, Rogg JM, Donahue JE, Machan JT, Goldman MA, Doberstein CE: Preoperative MRI evaluation of pituitary macroadenoma: Imaging features predictive of successful transsphenoidal surgery. AJR 195: 720-728, 2010

3. Campero A, Emmerich J, Socolovsky M, Martins C, Yasuda A, Campero AA, Rhoton A: Microsurgical anatomy of the sphenoid ostia. Clin Neurosci 17: 1298-1300, 2010

4. Cappabianca P, Cavallo LM, Colao A, Divitis ED: Surgical complications associated with the endoscopic endonasal transsphenoidal approach for pituitary adenomas. J Neurosurg 97:293-298, 2002

5. Chowdhury FH, Haque R, Islam S, Aich ML, Kawsar KA, Haque $\mathrm{M}$, Sarkar $\mathrm{MH}$ : Endonasal transsphenoidal approach to pituitary surgery: Experience of 55 cases. Bangladesh J Otorhinolaryngol 15(2): 45-49,2009

6. Ciric I, Ragin A, Baumgartner C, Pierce D: Complications of transsphenoidal surgery: Results of a national survey, review of the literature, and personal experience. Neurosurgery 40(2): 225-237,1997

7. D'Haens J, Rompaey KV, Stadnik T, Haentjens P, Poppe K, Velkeniers B: Fully endoscopic transsphenoidal surgery for functioning pituitary adenomas. A retrospective comparison with traditional transsphenoidal microsurgery in the same institution. Surg Neurol 72: 336-340, 2009

8. Gandhi CD, Christiano LD, Eloy JA, Prestigiacomo CJ, Post KD: The historical evolution of transsphenoidal surgery: Facilitation by technological advances. Neurosurg Focus 27 (3):1-8, 2009
9. Gendeh BS: Expanded endoscopic endonasal approach to anterior and ventral skull base: An evolving paradigm. ISRN Endoscopy Article 2013, ID 149841, 11 pages. Available at: http://dx.doi.org/10.5402/2013/149841

10. Gondim JA, Schops M, Almeida JP, Albuquerque LAF, Ferraz EGT, Barroso FAC: Endoscopic endonasal transsphenoidal surgery: Surgical results of 228 pituitary adenomas treated in a pituitary center. Pituitary 13: 68-77, 2010

11. Hill M, Chandra RK, Fishman AJ, Kern RC: Endoscopic transsphenoidal approaches to the sella. Oper Tech Otolaryngol 21: 51-55, 2010

12. Hofstetter C, Anand VK, Schwartz TH: Endoscopic transsphenoidal pituitary surgery. Oper Tech Otolaryngol 22: 206-214, 2011

13. Jho HD: Endoscopic transsphenoidal surgery. J Neuro-Oncol 54: 187-195, 2001

14. Kim BY, Son HL, Kang SG, Kim SW, Hong YK, Jeun SS, Kim SW, Cho JH, Jin Park YJ: Postoperative nasal symptoms associated with an endoscopic endonasal transsphenoidal approach. Eur Arch Otorhinolaryngol 270: 1355-1359, 2013

15. Kus LH, Rotenberg BW, Duggal N: Use of tissue glues in endoscopic pituitary surgery: A cost comparison. Can J Neurol Sci 37: 650-655, 2010

16. Lazaridis N, Natsis K, Koebke J, Themelis C: Nasal, sellar, and sphenoid sinus measurements in relation to pituitary surgery. Clin Anat 23: 629-636, 2010

17. Ogawa $T$, Matsumoto $K$, Nakashima $T$, Okano $M$, Ono $Y$, Fukushima K, Yuuen K, Akagi H, Nishizaki K: Hypophysis surgery with or without endoscopy. Auris Nasus Larynx 28: 143-149, 2001

18. Saad MSM, Gendeh BS, Husain S: Endonasal endoscopic transsphenoidal pituitary surgery for pituitary adenoma: A retrospective analysis of surgical outcome. Med J Malaysia 66(5): 443-446, 2011

19. Senior BA, Ebbert CS, Bednarski KK: Minimally invasive pituitary surgery. Laryngoscope 118:1842-1855, 2008

20. Tabaee A, Anand VK, Barron Y, Hiltzik DH, Brown SM, Kacker A, Mazumdar M, Schwartz TH: Endoscopic pituitary surgery: A systematic review and meta-analysis. J Neurosurg 111:545554,2009

21. Wagenmakers MAEM, Netea-Maier RT, Lindert EJV, Timmers HJLM, Grotenhuis JA, Hermus ARMM: Repeated transsphenoidal pituitary surgery (TS) via the endoscopic technique: A good therapeutic option for recurrent or persistent Cushing's disease (CD). Clin Endocrinol 70:274280, 2009

22. White DR, Sonnenburg RE, Ewend MG, Senior BA: Safety of minimally invasive pituitary surgery compared with a traditional approach. Laryngoscope 114:1945-1948, 2004 